\title{
Policy Recommendations to Reinvigorate Recycling in Arizona
}

\section{Erin L. Murphy*, Miranda L. Bernard, Levi Helm, Infynity Hill, Álex Tuñas-Corzón}

Arizona State University, School of Life Sciences, Tempe, AZ

http://doi.org/10.38126/ISPG170115

Corresponding author: elmurph1@asu.edu

Keywords: recycling; sustainability; waste management; Arizona; policy

Executive summary: In 2018, China enacted an import ban on twenty-four types of recyclables as part of its National Sword policy, upending recycling programs across the U.S. In Arizona, many municipalities have responded by significantly reducing or completely halting their programs, causing some cities to landfill their recyclables. We have reviewed state legislation and interviewed waste management coordinators to identify the key challenges and opportunities for recycling in Arizona. Informed by our interviews, we call on Arizona state legislators to (1) pass a resolution to appropriate funding for the recycling grant program, (2) amend this program to allow for joint applications, (3) repeal A.R.S. 9-500.38, 'Prohibition on regulation of auxiliary containers; state preemption; definition', (4) introduce a tax on products imported in single-use containers, and (5) provide incentives to companies using Arizona recyclables. These policies would reinvigorate recycling within the state, make Arizona's waste management systems more cost-effective, and foster new local processing and manufacturing industries.

\section{Introduction}

Recycling is a form of waste management that converts waste materials into new products (Environmental Protection Agency 2019). It first gained popularity in the 1970s due to concerns about limited landfill space (Louis 2004). However, the prevalence of U.S. recycling programs has increased, due to the environmental and economic superiority of recycling to the production of virgin (non-recycled) (Glass Packaging Institute 2010; Environmental Protection Agency 2016b; Gencer 2016). By 2017, roughly 35 percent of Americans participated in a public recycling program (Environmental Protection Agency 2019).

In 2018, the U.S. recycling sector was upended by China's National Sword policy. This policy banned the import of twenty-four types of waste, including all non-industrial plastics and paper (Qu et al. 2019). Until this point, China had been the primary importer of recyclable material from U.S. materials recovery facilities (MRFs) (Brooks et al. 2018). Without established national and international markets prepared to absorb this shock, millions of tons of U.S. recycling have been displaced (Brooks et al. 2018), forcing municipalities to reduce services or halt recycling programs altogether (Lieber 2019; Semuels 2019).

Arizona's recycling programs have not escaped these impacts. Several municipalities across the state have restricted or canceled their recycling programs over the last few years (municipality interviews). In this paper, we review the state of recycling in Arizona, and present policy recommendations to reinvigorate Arizona's recycling programs.

\section{Background on recycling.}

Waste management in the U.S., including recycling, occurs primarily at the municipality or county level (Louis 2004). Local jurisdictions provide public services or partner with industry to ensure solid waste collection and proper disposal (Louis 2004). Recycling providers offer services through curbside 
pick-up or drop-off locations (Louis 2004). Many offer single-stream collection, meaning individuals do not need to segregate their recyclable materials. Others require constituents to pre-sort their products. Collectors then bring recyclable materials to MRFs where processors remove contaminants (e.g., nonrecyclable products), sort products, and bale recyclables (Gershman, Brickner \& Bratton Inc. 2015). MRFs sell bales to conversion facilities (e.g., paper mills) that turn the materials into new products. Manufacturers then buy these products.

\section{Arizona's regulatory framework}

The existing regulatory framework in Arizona, A.R.S. 49-701 to 49-881, requires municipalities to ensure the safe and sanitary disposal of solid waste, including recyclable materials. These statutes, outlined in Table 1 within the appendix, create opportunities and barriers for municipal recycling.

\section{i. Opportunities}

The state allows municipalities to jointly operate equipment and facilities for waste management (A.R.S. 49-703). By cooperating, municipalities can avoid investing in expensive machinery and facilities alone, thereby capitalizing on economies of scale and using their financial resources more efficiently.

The state also authorized a recycling grant program (A.R.S. 49-837), which is funded by a landfill fee of $\$ 0.25$ per ton (A.R.S. 49-836). From 1992-2009, the state distributed over $\$ 17 \mathrm{M}$ through 339 grants that allowed municipalities to implement and maintain recycling and education programs (Arizona Department of Environmental Quality 2010). However, for the past decade, the state legislature has not appropriated any funds for this program (Shaw, Joseph B. Personal interview. October 29, 2019).

\section{ii. Barriers}

The state prohibits municipalities from imposing regulations on auxiliary containers (e.g., bags, food packaging; A.R.S. 9-500.38). This burdens municipalities with the responsibility of managing an ever-evolving waste stream created by packaged goods. For example, Phoenix is forced to shut down their MRF multiple times a day to disentangle plastic bags from their disc screen (equipment that separates single-stream waste), costing the city hundreds of thousands of dollars annually (municipality interview). This legislation also prohibits municipalities from requiring businesses or apartment complexes to offer recycling services (A.R.S. 9-500.38), decreasing the amount of recyclable material municipalities manage, and ultimately limiting economies of scale.

\section{Arizona's municipal recycling programs}

Recycling programs vary greatly across municipalities in Arizona. To gain a better understanding of how to improve state-wide waste management, we interviewed key informants from Arizona. Through these interviews, we identified key challenges and opportunities municipalities face.

\section{i. Methods}

We conducted semi-structured interviews with city officials and recycling managers from across the state. We contacted the largest city and county seat from every county and received responses from fourteen municipalities, representing twelve counties. Our interview guide included the following questions: (1) what products do you recycle, (2) how is your recycling program managed, (3) how has your recycling program changed over the last five years, and (4) what are the biggest challenges for your program? Answers to each question were categorized to identify patterns between municipalities.

Table 2 in the appendix summarizes the responses to questions 1 and 2. Below, we discuss the key challenges and opportunities identified through interview questions 3 and 4.

\section{ii. Challenges}

Participants from every program noted the increasing difficulties of maintaining recycling programs due to decreasing commodity revenues, lost grant opportunities and increasing operational costs. Recycling programs are maintained by the sale of recyclables, grants, and waste management fees paid by citizens. Almost every interviewee indicated that China had been an important buyer of their recyclables. There are not enough American-based processing plants to handle all of the recyclable waste produced in the U.S. Additionally, emerging international markets are unable to match the prices of the former Chinese markets, forcing municipalities to sell their products at remarkably lower prices. As a result, China's ban on imports directly reduced the market value of many recyclable products, reducing overall profits. For example, the city of Phoenix used 
to profit from the sale of paper, but now it costs more to recycle paper products than to landfill them. These market changes for recycled goods have reduced the profits of every municipality we interviewed, reducing the long-term viability of recycling for most programs unless new markets emerge. For example, in just two years, Sierra Vista's annual revenue decreased by $\$ 32,000$, a $75 \%$ drop from previous years.

Another challenge is that the recycling grant fund described in the previous section (Arizona's Regulatory Framework) is not being appropriated. Many interviewees noted that these grants were critical for the development and maintenance of their recycling programs and cited the disappearance of this funding stream as a serious hindrance. Since 2010 the funds collected for the recycling program have not been appropriated, though the landfill fee is still being collected by the state (Shaw, Joseph B. Personal interview. October 29, 2019).

Every interviewee also cited high operational costs (collecting, processing, and transporting materials) as a challenge for program feasibility. Consumers prefer single-stream, curbside recycling programs for convenience, but these programs have higher collection and processing costs. Interviewees noted the capital assets required for these recycling programs-trucks, equipment, and maintenancerequire significant upfront expenditures that were previously alleviated by the recycling grant program. Additionally, interviewees noted processing costs have increased due to high levels of contamination.

Transportation costs are high due to the lack of local markets for recyclable goods. As a result, recyclables must be transported to buyers outside of Arizonamostly in California, the Eastern U.S., or internationally. Oftentimes these combined operational costs are higher than the value of the product. In many rural communities, recyclables are transported to Phoenix or Tucson. Kingman and Eagar have sent recyclables to Las Vegas, NV and Albuquerque, NM, respectively. Though sending recyclables to large cities reduces processing costs, transportation costs for these municipalities can still be higher than subsequent profits.

Every city has been forced to alter its operations and noted citizens were disappointed by these changes.
Casa Grande, Eagar, Holbrook, Payson, Nogales, and Sierra Vista- $43 \%$ of programs interviewed-have halted recycling altogether because it is no longer financially viable. Bisbee, Kingman, and Sedona$21 \%$ of interviewed municipalities-only offer recycling at drop-off locations to reduce collection costs; however, this strategy reduces participation. For example, before Sierra Vista ceased recycling, they noted participation rates dropped from $50 \%$ to $10 \%$ when they transitioned from pick-up to drop-off services. Finally, the city of Phoenix recently voted to increase its monthly solid waste fees to ensure there would be no reduction in services provided to their constituents.

\section{iii. Opportunities}

Our interviews with city officials and recycling managers highlighted opportunities to increase the viability of Arizona recycling by increasing revenue and decreasing costs. Many interviewees noted that local processing facilities are critical to this shift. Several-including Phoenix, Bisbee, Flagstaff, and Sedona-stated that unlike other materials, glass recycling has become more profitable over the last few years because Strategic Materials, a private company, opened a processing plant in Phoenix. This facility processes 50,000 tons of glass a year, which is mostly sourced from within Arizona. Municipalities noted this significantly reduced their transportation costs, making glass recycling viable for the first time in a while. Interviewees believe that building processing plants for other materials in Arizona would further reduce transportation costs and increase the overall viability of their recycling programs. Interviewees also identified an opportunity associated with creating local-end markets. Not only would this increase the efficiency of recycling within the state, but it would also bolster the local economy. For example, the U.S. Environmental Protection Agency estimates that for every one thousand tons of materials recycled in the U.S., 1.57 jobs are created generating \$76,030 in wages and $\$ 14,101$ in tax revenues (Environmental Protection Agency 2016b).

\section{Policy recommendations}

Based on our findings, we have developed the following policy recommendations to improve waste management and recycling in Arizona, which may be implemented jointly or independently. When 
applicable, we present advantages and disadvantages that we have identified.

\section{i. Reccommendation 1}

Appropriate A.R.S. 49-837 'Recycling fund; use; advisory committee'. This formal resolution would ensure that money currently collected through the landfill fee (A.R.S. 49-836) is appropriated to recycling grants instead of being swept into general funds.

\section{Advantages}

As the profitability of recycling has dropped, appropriating these funds is more critical than ever. It will increase municipalities' capacity to recycle and allow them to implement education programs, reducing contamination costs. This may ultimately reduce the financial burden on citizens by allowing for lower municipal solid waste fees.

\section{Disadvantages}

This will affect the state's general fund (i.e. funds used for the state budget). However, the last time funds were appropriated, in 2009, this grant only made up $0.012 \%$ of the enacted budget (Office of the Governor $2009,6)$.

\section{ii. Recommendation 2}

Amend A.R.S. 49-837 'Recycling fund; use; advisory committee'. We propose an expansion of the recycling grant program to allow applicants to co-apply for grants. Municipalities are already authorized to jointly operate recycling programs and equipment (A.R.S. 49-703). This amendment would strengthen the benefits of this statute by allowing, for example, two towns to apply to purchase one truck that could service both municipalities.

\section{Advantages}

Collection and processing of recyclables are disproportionately expensive for small communities. Allowing municipalities to co-apply for grants and share capital assets would foster more efficient use of funds and municipal resources by reducing the amount of staff and equipment needed.

\section{iii. Recommendation 3}

Repeal A.R.S. 9-500.38 'Prohibition on regulation of auxiliary containers; state preemption; definition'. This statute prevents municipalities from governing the sale, use, or disposal of auxiliary containers in their jurisdiction by prohibiting any local policy. This includes product bans or recycling mandates for businesses. Waste is managed at the local level, therefore the cost of disposing of auxiliary containers falls on the municipality. Repealing this statute would return authority to municipalities, allowing them to better manage their waste stream by regulating the types of products they receive and ensuring the disposal of high-quality materials.

\section{Advantages}

Recycling costs for municipalities and citizens would decline. Businesses produce a significant recycling stream. Interviewees noted that mandating businesses to recycle would reduce the marginal cost of recycling by creating economies of scale (Bohm et al. 2010). Additionally, certain auxiliary containers significantly increase the cost of processing waste (e.g. the example above of plastic bags increasing sorting costs for the city of Phoenix). By allowing municipalities to implement bans or taxes on auxiliary products, they can remove products that are expensive to manage from the waste stream, tax these products to offset the cost of their management, or incentivize the use of alternatives through credits.

\section{Disadvantages}

Inconsistencies that emerge between municipalities may be viewed as an inconvenience to consumers. Additionally, depending on the response of municipalities, bans or taxes on auxiliary containers may increase costs for businesses or prices for the end consumer (United Nations Environmental Programme 2018).

\section{iv. Recommendation 4}

Tax imported single-use containers. Many single-use containers in Arizona are imported from out of state. However, the cost of disposing these containers falls on municipalities. This bill would introduce a tax on imported products packaged in single-use containers made from virgin plastics.

\section{Advantages}

This is an example of an extended producer responsibility (EPR) policy. It would shift the cost of managing waste from the public to the producers of these hard to recycle products, thus incorporating the costs of treatment and disposal into the total cost of production. Further, EPR would give a competitive advantage to local businesses. Projections from a 
similar policy initiative in California suggest that an EPR tax could increase tax revenue by several billion dollars annually (Petek and Bosler 2019).

\section{Disadvantages}

The costs of EPR schemes can be displaced to the consumers through increased prices. Therefore, this policy may disincentivize certain businesses from selling their products in Arizona or cause businesses to increase prices for consumers to offset the associated costs.

\section{v. Recommendation 5}

Incentivize use of Arizona recyclables. This bill would provide financial incentives (e.g., subsidies, tax breaks) to Arizona businesses that buy local recyclables, process recyclables, or manufacture products using locally recycled materials. Phoenix has already rezoned fifty acres of land around their transfer station and MRF for the development of local conversion plants; this proposal incentivizes companies to take advantage of this opportunity.

Advantages: This would create more local endmarkets, reduce transportation costs, and increase the value of recyclables. Currently, there is a large gap in the U.S. market for recyclables (Lieber 2019). With proper investment a new industry could emerge, creating jobs and revenue for Arizonans.

\section{Conclusion}

Changes in international recycling markets have significantly impacted recycling programs in the U.S. In Arizona, recycling managers have identified decreasing revenue from the sale of recyclables and high operational costs as challenges to their recycling programs. As a result, programs across the state have cancelled or modified their recycling operations. We present state-level policy recommendations to reinvigorate Arizona's recycling programs by decreasing operational costs and increasing revenue.

\section{Appendix: Tables}

\begin{tabular}{|l|l|}
\hline Statute & Description \\
\hline A.R.S. 49-703 'Joint operation' & $\begin{array}{l}\text { Permission for municipalities to partner with other } \\
\text { municipalities or the private sector to collect, process, } \\
\text { or sell recyclables }\end{array}$ \\
\hline $\begin{array}{l}\text { A.R.S. 49-746 'Private enterprise recycling } \\
\text { and solid waste management; definitions' }\end{array}$ & $\begin{array}{l}\text { Prohibition on municipalities from requiring the use } \\
\text { of public waste management services }\end{array}$ \\
\hline $\begin{array}{l}\text { A.R.S. 49-836 'Solid waste landfill disposal } \\
\text { fees' }\end{array}$ & $\begin{array}{l}\text { Requirement of parties to pay a fee of twenty-five } \\
\text { cents per ton of waste disposed of in each landfill }\end{array}$ \\
\hline $\begin{array}{l}\text { A.R.S. 49-837 'Recycling fund; use; advisory } \\
\text { committee' }\end{array}$ & $\begin{array}{l}\text { Half of funds from A.R.S. 836 shall fund a recycling } \\
\text { grant program, which helps municipalities implement } \\
\text { recycling programs and educate citizens }\end{array}$ \\
\hline $\begin{array}{l}\text { A.R.S. 9-500.38 'Prohibition on regulation of } \\
\text { auxiliary containers; state preemption; } \\
\text { definition' }\end{array}$ & $\begin{array}{l}\text { Prohibits regulation of the sale, use or disposal of } \\
\text { auxiliary containers (e.g., bags, food packaging, and } \\
\text { bottles) made from any product }\end{array}$ \\
\hline
\end{tabular}

Table 1 : Relevant statutory laws regarding waste management and recycling in the state of Arizona 


\begin{tabular}{|c|c|c|c|c|}
\hline Locale & $\begin{array}{l}\text { Populat } \\
\text { ion }\end{array}$ & $\begin{array}{l}\text { Materials } \\
\text { recycled }\end{array}$ & Collection & Description \\
\hline Phoenix & $\begin{array}{l}1,660,2 \\
72\end{array}$ & $\begin{array}{l}\text { Plastic }(1,2,5), \\
\text { Glass, Cardboard, } \\
\text { Paper, Glass, } \\
\text { Metal }\end{array}$ & $\begin{array}{l}\text { Single-stream, } \\
\text { Curbside }\end{array}$ & $\begin{array}{l}\text { City collects waste and contracts with a } \\
\text { private company who sorts and sells. } \\
\text { City owns their own capital assets } \\
\text { (transfer station, MRF, equipment). }\end{array}$ \\
\hline Tucson & 520,116 & $\begin{array}{l}\text { Plastic (1-7), } \\
\text { Glass, Cardboard, } \\
\text { Paper, Metal }\end{array}$ & $\begin{array}{l}\text { Single-stream, } \\
\text { Curbside }\end{array}$ & $\begin{array}{l}\text { City collects waste and brings it to } \\
\text { Republic Services' MRF, who sorts and } \\
\text { sells waste. }\end{array}$ \\
\hline Flagstaff & 73,964 & $\begin{array}{l}\text { Plastic }(1,2) \text {, } \\
\text { Glass, Cardboard, } \\
\text { Paper, Metal }\end{array}$ & $\begin{array}{l}\text { Single-stream } \\
\text { (excl. glass), } \\
\text { Curbside }\end{array}$ & $\begin{array}{l}\text { City collects waste, brings glass to } \\
\text { Strategic Materials, and the rest to } \\
\text { privately-owned MRF. }\end{array}$ \\
\hline $\begin{array}{l}\text { Casa } \\
\text { Grande }\end{array}$ & 55,477 & None & $\mathrm{N} / \mathrm{A}$ & $\begin{array}{l}\text { Cancelled program in July } 2019 \text { due to } \\
\text { transport costs and decreasing profits }\end{array}$ \\
\hline $\begin{array}{l}\text { Sierra } \\
\text { Vista }\end{array}$ & 42,912 & None & $\mathrm{N} / \mathrm{A}$ & $\begin{array}{l}\text { Cancelled program in } 2020 \text { due to } \\
\text { transport costs and decreasing profits } \\
\text { after switching to single- stream, drop- } \\
\text { off }\end{array}$ \\
\hline Prescott & 39,843 & $\begin{array}{l}\text { Plastic }(1,2) \text {, } \\
\text { Glass, Cardboard, } \\
\text { Paper, Metal }\end{array}$ & $\begin{array}{l}\text { Single-stream, } \\
\text { Curbside }\end{array}$ & $\begin{array}{l}\text { Commingled recyclables are collected } \\
\text { by the city and transported to Phoenix } \\
\text { MRF. }\end{array}$ \\
\hline Kingman & 28,068 & $\begin{array}{l}\text { Plastic }(1,2) \text {, } \\
\text { Glass, Cardboard, } \\
\text { Paper, Metal }\end{array}$ & $\begin{array}{l}\text { Pre-sorted, } \\
\text { Drop-off }\end{array}$ & $\begin{array}{l}\text { City transports paper and glass to Las } \\
\text { Vegas (Republic Service and Strategic } \\
\text { Materials) and metal and plastic to a } \\
\text { privately-owned, local MRF. }\end{array}$ \\
\hline Nogales & 20,188 & None & $\mathrm{N} / \mathrm{A}$ & Cancelled due to high costs \\
\hline Somerton & 16,120 & $\begin{array}{l}\text { Plastic (1-7), } \\
\text { Glass, Paper, } \\
\text { Cardboard, Glass, } \\
\text { Metal }\end{array}$ & $\begin{array}{l}\text { Single-stream, } \\
\text { Curbside }\end{array}$ & $\begin{array}{l}\text { City collects waste. Inmates sort waste. } \\
\text { City stores waste until it can be sold in } \\
\text { bulk. }\end{array}$ \\
\hline Payson & 15,520 & None & $\mathrm{N} / \mathrm{A}$ & $\begin{array}{l}\text { Cancelled in } 2019 \text { due to too high } \\
\text { contamination rates. }\end{array}$ \\
\hline Sedona & 10,336 & $\begin{array}{l}\text { Plastic (1-7), } \\
\text { Glass, Cardboard, } \\
\text { Paper, Metal, } \\
\text { Styrofoam }\end{array}$ & $\begin{array}{l}\text { Pre-sorted, } \\
\text { Drop-off }\end{array}$ & $\begin{array}{l}\text { Sedona Recycles (501c3) collects and } \\
\text { processes waste and sells to U.S.-based } \\
\text { companies. }\end{array}$ \\
\hline Bisbee & 5,575 & $\begin{array}{l}\text { Plastic }(1,2) \text {, } \\
\text { Glass, Cardboard, } \\
\text { Paper, Metal }\end{array}$ & $\begin{array}{l}\text { Pre-sorted, } \\
\text { Drop-off }\end{array}$ & $\begin{array}{l}\text { City collects waste, brings glass to } \\
\text { Strategic Materials, and the remaining } \\
\text { materials to Tucson. }\end{array}$ \\
\hline Holbrook & 5,053 & None & $\mathrm{N} / \mathrm{A}$ & $\begin{array}{l}\text { Cancelled program because no private } \\
\text { company found it profitable. }\end{array}$ \\
\hline
\end{tabular}




\begin{tabular}{|l|l|l|l|l|}
\hline Eagar & 4,881 & None & N/A & $\begin{array}{l}\text { Cancelled program due to high } \\
\text { transport costs. Not cost effective with } \\
\text { market changes. }\end{array}$ \\
\hline
\end{tabular}

Table 2: Description of recycling in all municipalities interviewed. Data include each city's population, the materials their programs accept, how recyclables are collected, and who is involved in the process.

\section{References}

Arizona Department of Environmental Quality. 2010. "Quick Facts about ADEQ Recycling Program." Bohm, Robert A., David H. Folz, Thomas C.

Kinnaman, and Michael J. Podolsky. 2010 "The costs of municipal waste and recycling programs." Resources, Conservation and Recycling 54(11): 864-871. https://doi.org/10.1016/i.resconrec.2010.01.00 $\underline{5}$

Brooks, Amy L., Shunli Wang, and Jenna R. Jambeck. 2018. "The Chinese import ban and its impact on global plastic waste trade." Science Advances 4(6): eaat0131. https://doi.org/10.1126/sciadv.aat0131

Environmental Protection Agency. 2016. "Paper Grades and Collection." Last modified February 21, 2016.

https://archive.epa.gov/wastes/conserve/materi als/paper/web/html/grade.html

Environmental Protection Agency. 2019. "Advancing sustainable materials management: 2016 and 2017 Tables and Figures." 530-F-19-007, Washington, D.C. https://www.epa.gov/sites/production/files/20 $\underline{19-}$

11/documents/2016 and 2017 facts and figure s data tables 0.pdf

Gencer, Y.G. 2016. "Mystery of recycling: Glass and aluminum examples." In Handbook of research on waste management techniques for sustainability: 172-191. IGI Global. https://doi.org/10.4018/978-1-4666-97232.ch009

Gershman, Brickner, and Bratton Inc. 2015 "The Evolution of Mixed Waste Processing Facilities 1970Today." Prepared for the American Chemistry Council.

https://plastics.americanchemistry.com/Educati on-Resources/Publications/The-Evolution-ofMixed-Waste-Processing-Facilities.pdf

Glass Packaging Institute. 2010. "Environmental Overview Complete Life Cycle Assessment of North

American Container Glass." Alexandria, VA: Glass Packaging Institute. https://assets.noviams.com/novi-fileuploads/gpi/pdfs-anddocuments/Press_Releases/.pdf
Lieber, C. 2019. "Hundreds of US cities are killing or scaling back their recycling programs." Vox. March 18, 2019. https://www.vox.com/thegoods/2019/3/18/18271470/us-cities-stoprecycling-china-ban-on-recycles

Louis, Garrick E. 2004. "A historical context of municipal solid waste management in the United States." Waste management \& research 22(4): 306-322. https://doi.org/10.1177/0734242X04045425

Office of the Governor. "The executive budget summary fiscal years 2010 and 2011" Janet Napolitano. 2009. Phoenix, AZ. http://www.azospb.gov/documents/2009/1_20 10-2011-Summary-Final.pdf

Petek, G, Keely Martin Bosler. 2019. https://lao.ca.gov/ballot/2019/190644.pdf

Qu, S., Yuhua Guo, Zijie Ma, Wei-Qiang Chen, Jianguo Liu, Gang Liu, Yutao Wang and Ming Xu. 2019. "Implications of China's foreign waste ban on the global circular economy." Resources, Conservation and Recycling, 144: 252-255.

https://doi.org/10.1016/i.resconrec.2019.01.00 $\underline{4}$

Semuels, A. 2019. "Is this the end of Recycling?" The Atlantic. March 5, 2019.

https://www.theatlantic.com/technology/archiv e/2019/03/china-has-stopped-accepting-ourtrash/584131/

United Nationals Environmental Programme. "Legal Limits on Single-Use Plastics and Microplastics: A Global Review of National Laws and Regulations." Carole Excell, Celine Salcedo-La Viña, Jesse Worker, and Elizabeth Moses. 2018. http://hdl.handle.net/20.500.11822/27113

Wang, C., Longfeng Zhao, Ming K. Lim, Wei-Qiang Chen and John W. Sutherland. 2020. "Structure of the global plastic waste trade network and the impact of China's import Ban." Resources, Conservation and Recycling 153: 104591. https://doi.org/10.1016/j.resconrec.2019.10459 $\underline{1}$ 
Erin Murphy is a Ph.D. student at Arizona State University in the Conservation Innovation Lab. She is interested in developing sustainable and equitable solutions to marine conservation challenges by bridging the gap between research, policy, and management. Erin received her B.S. in Integrative Biology and M.Sc. in Geology at the University of Illinois at Urbana-Champaign. @Erin_Murphy2

Miranda Bernard is a Ph.D. candidate in the Environmental Life Sciences department at Arizona State University. Her research interests center on understanding the roles of community knowledge and perceptions in marine conservation interventions, namely protected areas. @mirandalbernard

Levi Helm is a Ph.D. student at Arizona State University in the Ecology, Economics, and Ethics of the Environment program. He studies how to mitigate trade-offs and unintended consequences in developing environmental policy. Levi received his B.S. from the University of Virginia where he studied Environmental Science and Anthropology. @levihelm

Infynity Hill is a master's student at Arizona State University in the Conservation Innovation Lab. Infynity is interested in researching how municipalities manage their solid waste and designing strategies to mitigate the environmental and human health impacts of solid waste management. Infynity earned her B.S. in Health Sciences at Arizona State University.

Alex Tuñas is a biologist interested in understanding the causes and consequences of global change in relation to biodiversity loss and ecosystem functioning. He earned a BSc in Biology at the University of Santiago de Compostela, an MRes in Ecology, Evolution and Conservation at Imperial College London and an MSc in Environmental Life Sciences at Arizona State University. 